\title{
APOCYNACEAE
}

The subfamily Periplocoideae currently forms part of the family Apocynaceae (Venter \& Verhoeven 1997). This subfamily was previously classified as a section (Brown 1810) or subfamily (Schumann 1895) of the Asclepiadaceae. or as a separate family. the Periplocaceac (Schlechter 1914). The Asclepiadaceade has been studied extensively by especially Albers (Albers 1979. 1983 . Albers \& Delfs 1983) hut as far as can be ascertained. almost no cytogenetic data have been published on the Periplocoideate. The aim of this paper is to contribute to the cytogenetic knowledge of the Apocynaceae in general. and the Periplocoideace in particular.

\section{MATERIAI.S AND METHODS}

Cytogenetic material was collected and fixed in the field (Spies \& Du Plessis 1986). The material used and their localities are listed in Table 3. Voucher specimens are housed in the Geo Potts Herbarium. Department of Botany and Genetics. University of the Orange Free State. Bloemfontein (BLFU).

Anthers were squashed in aceto-carmine and meiotically analysed (Spies et al. 1996). Chromosome numbers are presented as gametic chromosome numbers to conform to previous papers on chromosome numbers in this journal (Spies \& Du Plessis 1986).

\section{RESULTS AND DISCLSSION}

Twenty specimens, representing 10 species and four genera. were studied (Table 3). All specimens proved to be diploid ( $2 \mathrm{n}=2 \mathrm{x}=22$ ) with a basic chromosome number $x=11$. 
TABLE 3.-Gametic chromosome numbers of specimens of Periplocoideae, with voucher specimen numbers and specific localities

Taxon Voucher n Collecting locality

Tribe Periploceae Bartl.

Tacazzea apiculata Oliv.

Venter 9248
Venter 9250
Venter $9251,9252.9253$
$\quad 9322$

11 KWAZULU-NATAL. - 2732 (Ubombo): Makane's Drift. (-AB)

11 KWAZULU-NATAL_-2732 (Ubombo): Sordwana. (-DA).

9322

\section{Tribe Gymnanthereae Venter}

Raphionacme dyeri Retief \& Venter

R. galpinii Schltr.

R. hirsuta (E.Mey.) R.A.Dyer

R. procumbens Schltr

Du Preez 2548

Du Preez 2565

Venter 9269

Du Preez 2531

Venter 9309

Venter 9260
KWAZULU-NATAL. - 2832 (Mtubatuba): Richards Bay next to Mzingazi Lake, (-CC).

\section{Tribe Cryptolepideae Venter}

Cryptolepis cryptolepioides (Schltr.) Bullock

C. obtusa N.E.Br.

Ectadium latifolium (Schinz) N.E.Br.

E. rotundifolium (H.Huber) Venter

\& Kotze

E. virgatum E.Mey

Venter 9182,9183
Venter 9181
Venter 9299
Venter 9314
Venter 9313
Venter 9312

Venter 9237
FREE STATE.-2826 (Brandfort): Soetdoring Nature Reserve, (-CC).

11 FREE STATE. - 2926 (Bloemfontein): Rustfontein Dam. (-BC).

11 KWAZULU-NATAL. - 2732 (Ubombo): Lebombo Mountains near Josini, (-AA)

11 FREE STATE.-2827 (Senekal): Evening Star, Clocolan, (-CD).

11 FREE STATE. - 2926 (Bloemfontein): Brandkop Racing Track, (-AA).

11 MPUMALANGA.-2430 (Pilgrim's Rest): Blyderivier Canyon, (-DB)

\section{Tribe Periploceae}

Tacazzea apiculata is the only species being studied cytogenetically (Table 3 ).

\section{Tribe Gymnanthereae}

Chromosome numbers are reported for the first time in Raphionacme dyeri, $R$. galpinii, $R$. hirsuta, $R$. procumbens and $R$. zeyheri. This number of $2 \mathrm{n}=2 \mathrm{x}=22$ is confirmed for $R$. flanaganii Schltr., which was previously studied by F. Albers (pers. comm.).

\section{Tribe Cryptolepideae}

This is the first report for any African species in this tribe. The chromosome number of $2 n=2 x=22$ found in
Cryptolepis cryptolepioides, C. obtusa, Ectadium latifolium, E. rotundifolium and E. virgatum (Figure 7), corresponds with those chromosome numbers previously noted for certain Asian species of this tribe, i.e. Cryptolepis buchananii Roem. \& Schult. (Sharma 1970; Navaneetham 1982), C. grandiflora Wight (Navaneetham 1982; Navaneetham \& Sampathkumar 1984) and C. sinensis (Lour.) Merr. [= C. elegans Wall.] (Navaneetham 1981).

\section{ACKNOWLEDGEMENTS}

The University of the Orange Free State and the National Research Foundation are thanked for financial assistance during this study.

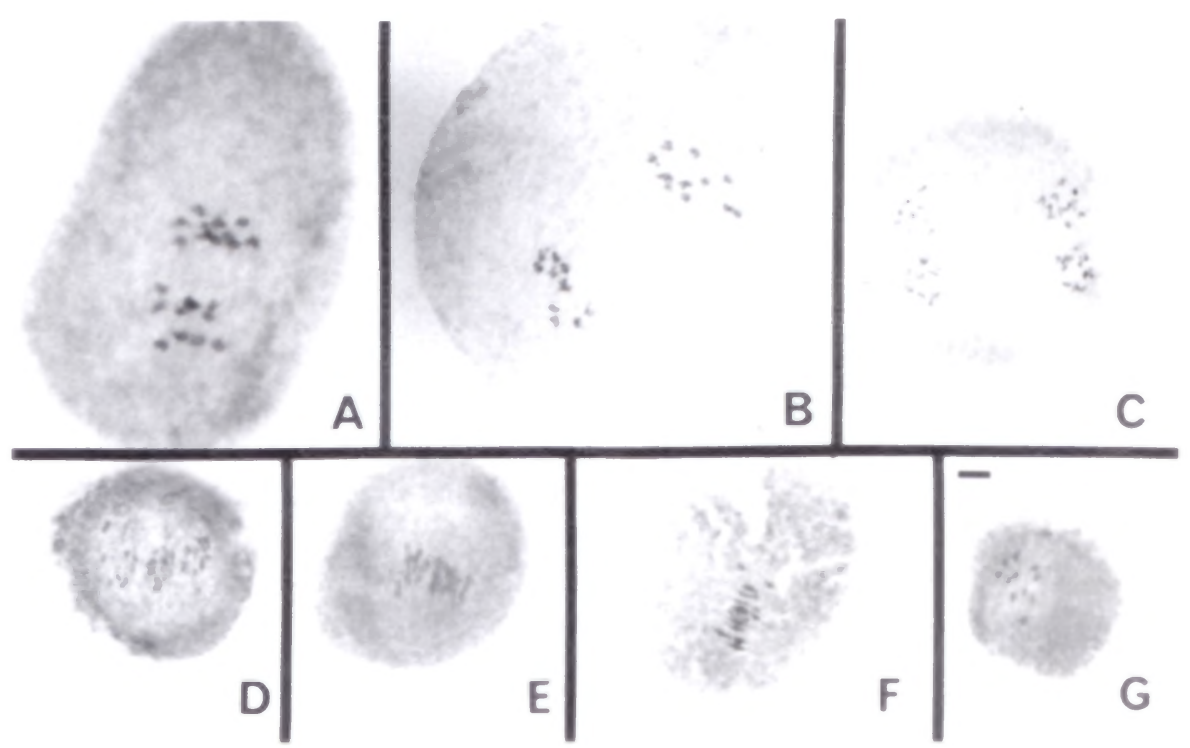

FIGURE 7.-Meiotic chromosomes $(2 \mathrm{n}=2 \mathrm{x}=22)$ in representatives of the Apocynaceac. A. Tacazea apiculata. Venter 9252, anaphase I. B. C. T apiculata. Venter 9322: B. anaphase I: C. anaphase II. D. Raphionacme hirsuta. Venter 9309. early anaphase I: E. Cryptolepis cruptolepiodes. Venter 9181. metaphase I: F, Ectadium rotundifolium, Ven. ter 9313. metaphase I: G. E. virgatum, Venter 9237 . diaki nesis. Scale bar: A-F, $6.4 \mu \mathrm{m}$; G. $8.3 \mu \mathrm{m}$. 


\section{REFERENCES}

ALBERS. F. 1979. Chromosome studies in the Stapeliads. Aloe 17:85-90. ALBERS, F. 1983. Cytotaxonomic studies in African Asclepiadaceae. Bothalia 14: 795-798.

ALBERS. F. \& DELFS. W. 1983. IOPB Chromosome number repors LXXXI. Taxon 32: 667. 668 .

BROWN. R. 1810. On the Asclepiadeae, a natural order of plants separated from the Apocrneae of Jussieu. London.

NAVANEETHAM. N. 1981. IOPB Chromosome number reports LXXII. Taxom 30: 696.

NAVANEETHAM. N. 1982. Karyomorphological studies in two species of Cruptolepis R.Br. Proceedings of the Indian Scientific Congresss Association 69: 231. 232

NAVANEETHAM. N. \& SAMPATHKUMAR. R. 1984. IOPB Chromosome number reports LXXXII. Taxon 33: 126-134.

SCHLECHTER. R. 1914. Periplocaceae. In J. Mildbraed. Wissenschaffliche Ergebnisse der deutschen Zentral-Afrika-Expedition 19(1)7-19()8. Leipzig.

SCHUMANN. K. 1895. Asclepiadaceae. Die natirlichen Pflanzen. familien, 4.2. Leipzig.

SHARMA. A.K. 1970. Annual report. 1967-1968. Research Bulletin of the University of Calcutta 2: 1-50. (Quoted in Goldblatt. P. 1981. Index to plant chromosome numbers 1975-1978. Monographs in Systematic Botany 5.)

SPIES. J.J. \& DL PLESSIS. H. 1986. Chromosome studies on African plants. 1. Bothalia 16:87, 88 .

VENTER. H.J.T. \& VERHOEVEN. R.L. 1997. A tribal classification of the Periplocoideae (Apocynaceae). Taxon 46: 705-720.

\section{J.J. SPIES*. H.J.T. VENTER* and S.M.C. VAN WYK*}

* Department of Botany and Genetics. University of the Orange Free State. P.O. Box 339. 9300 Bloemfontein.

MS received: $20(0)-06-30$ 